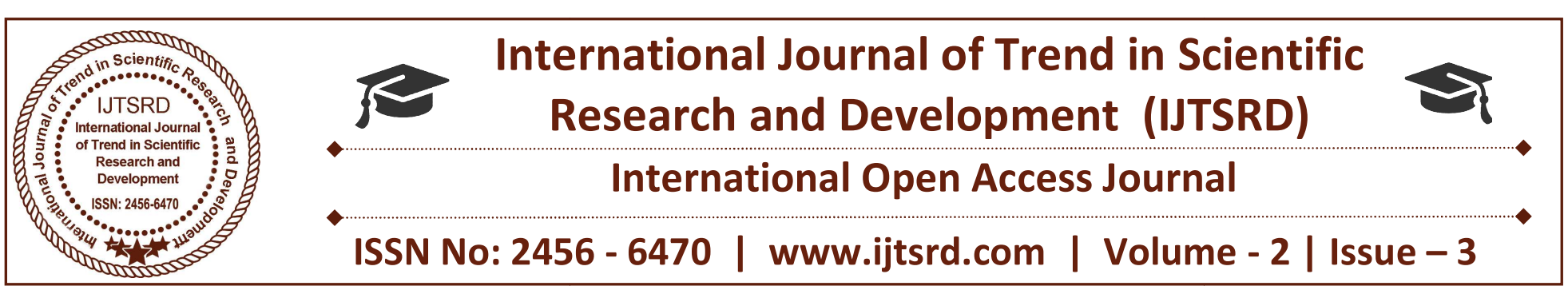

\title{
Assessment of Water Quality Status of Godavari river around process industries at Manuguru, Telangana State
}

\author{
Dr. Suresh Shukla \\ Department of Atomic Energy, Heavy Water Plant, \\ Manuguru, Telangana, India
}

\author{
Prof. Dr. M. A. Singaracharya \\ Department of Microbiology, Kakatiya University, \\ Warangal, Telangana, India
}

\begin{abstract}
The water quality was assessed by monitoring various physico-chemical parameters like temperature, $\mathrm{pH}$, hydrogen sulphide, total dissolved solids (TDS), biological oxygen demand (BOD), chemical oxygen demand (COD), sulphate, oil and grease and chloride (Cl-). The assessed quality of intake water and effluent water after treatment was studied. The treated waste water quality was compared with the permissible standards prescribed by Telangana State Pollution Control Board (TSPCB) and found well within the limits. This water could be successfully utilized for irrigation and horticulture purposes.
\end{abstract}

Keywords: Industrial effluents, Water characteristics, Irrigation water, Heavy water plant (HWP)

\section{INTRODUCTION:}

Water is one of the most common compounds on our planet and is essential to sustain all living beings. The raw water for any chemical industry by name itself indicates one of the starting raw materials used to process for the gain of desired product. Manuguru is a census town and mandal in Bhadradri Kothagudem district in the Indian state of Telangana. It comes under Mahaboobabad parliamentary constituency and Pinapaka Assembly constituency. Manuguru is an urban area, situated on the banks of Godavari River. Town is famous for Singareni coal mines. The nature and extent of water impurities depend upon the source of water (rain, surface and ground). The most common impurities are $\mathrm{pH}, \mathrm{SS}, \mathrm{BOD}, \mathrm{COD}$, TDS etc. The basic constituents which can pose threat to environment are mainly temperature, $\mathrm{pH}, \mathrm{TDS}, \mathrm{H} 2 \mathrm{~S}$, BOD, COD, Oil and Grease, Chloride (Cl-) and
Sulphate. Karthikeyan et al (2002) assessed the water quality of river amravati and recorded elevated levels of TDS owing to heavy influx of industrial effluents of different kinds. The high pollution in river cauveri by direct contamination of sewage and industrial effluents was recorded (Mathivanan et al (2007). Kashyap (2016) studied the TDS, conductance and hardness for their increased values towards the urban water as compared to rural water. The physicochemical properties of water from Gorai river in Kushtia, Bangladesh was studied for $\mathrm{pH}$, sulphate, chloride, TDS, etc and most parameters were exceeded the permissible limits (Nehar et al (2016). Rani et al (2011) studied river system as physical resource used for domestic, industrial and agricultural purposes as means of water disposal, transportation, getting food resources and recreational activities. Both organic and inorganic waste effluents interact adversely with river system deteriorating water quality of river which leads the adverse effects on surrounding land and aquatic ecosystem as well as subsequent impact on livelihood of local community (Rehman et al 2012, Meghla et al 2013).

\section{Materials and Methods:}

The water samples for both raw water and treated waste water were collected in sterile plastic bottles. The $\mathrm{pH}$ of water sample was estimated immediately after collecting water at site itself. The total dissolved solids, TDS, BOD, COD, Chloride, SO4, Oil and Grease as well as Sulphide were estimated as per procedure given in APHA (1987). The samples were collected in fortnightly intervals for a period of one year. The data obtained in the analysis were presented 
in Table 1 to 6 . The water quality was assessed and compared with the standards imposed by TSPCB.

\section{RESULTS AND DISCUSSIONS:}

Based on pilot plant observation and results validating above data good practice plants have been cited below. The samples analysis comparison at one of the Heavy Water Plants at Manuguru have been validated. In the present study, $\mathbf{p H}$ of all samples tested was observed between 6.9 to 8.6 which are slightly on alkaline side. High $\mathrm{pH}$ in summer may be due to high decomposition activities. Aquatic organisms need the $\mathrm{pH}$ of their water body to be a certain range optimal growth and survival. the $\mathrm{pH}$ of water is important for the biotic communities as most of the plant and animal species can survive in narrow range of $\mathrm{pH}$ from slightly acidic to slightly alkaline condition (Goher,M 2002). The maximum $\mathrm{pH}$ reported during summer was due to the water levels and concentration of nutrients in water (Narayana et.al 2008) and minimum was during monsoon due to the dilution of water by addition of rain water (Reddy et.al 2009).

The SS level was noticed varying in the range 2 to 7 ppm (Table1 and 4) in most months of the year in treated waste water. The SS are an extremely important cause of water quality deterioration leading to aesthetic issues, higher costs of water treatment, a decline in the fisheries resource, and serious ecological degradation of aquatic environments.

Biochemical oxygen demand: Biochemical oxygen measures the amount of oxygen that microorganisms consume while decomposing organic matter, it also measures the chemical oxidation of inorganic matter BOD is a measure of organic material contamination in water, specified in ppm. BOD is the amount of dissolved oxygen required for the biochemical decomposition of organic compounds and the oxidation of certain inorganic materials (e.g., iron, sulphites).

BOD has traditionally been the most important measure of strength of organic pollution. The BOD level was observed varying in the range of 1.2 to 2.0 ppm, in the months Sept'06 and November 06 (Table $4 \& 5)$.
Chemical oxygen demand(COD): The chemical oxygen demand test procedure is based on the chemical decomposition of organic and inorganic contaminants, dissolved or suspended in water. COD level was found varying between 5 to $24 \mathrm{ppm}$ in the months Mar'06 and May 06 (Table 1 \& 2) in river water. In treated waste water it was max. $20 \mathrm{ppm}$ in the month of September 06 (Table4).

TDS concentration of river water was noticed 266 ppm in the period March06(Table 1) during the study. The lowest TDS was noticed 96 ppm (July 06, Table 3 ) for river water and In treated waste water it was max. 33 ppm (January 07, table 6). TDS concentration in the body of water indicates the usefulness of water for various applications. TDS level hence is observed far less than the stated value of APPCB (2100 ppm).

The Oil \& Grease content in water destined for drinking or any other application is not acceptable. The oil \& grease was observed 1 ppm in most of the months during the present studies. The oil \& grease level prescribed by APPCB is $10 \mathrm{ppm}$ and hence it is much less than the permissible limit.

Sulphide (S--) was observed to be less than $5 \times 10^{-2}$ ppm (less than $50 \mathrm{ppb}$ ) in all samples for analysis. The sulphide content in Treated waste water samples is observed far less in comparison to the TSPCB limit (2 ppm).

Sulphates(SO4):All contaminated and waste water have normally high sulphate concentration (Rump \& Christ, 1992). In the present investigation, sulphate concentration was recorded max. 31 ppm(March06, table1) and min. 8 ppm ( Nov.06 and Jan.07, tables5 and 6)in river water and in treated waste water it was max. 9 ppm (March06,table1).

Chloride is one of the major inorganic anions in water and waste water. In the analysis of chloride level in rivr water, most samples revealed chloride variation in the range of $11 \mathrm{ppm}$ (July06, table3) to 28 ppm (May06;table2). In Treated waste water the chloride level was found max. 9 ppm (May 06,Table2) which is much below the permissible limit (1000 ppm). 
International Journal of Trend in Scientific Research and Development (IJTSRD) ISSN: 2456-6470

Table 1 : Water quality parameters of river Godavari and treated waste water quality discharged to river Godavcari from chemical process plant at Manuguru.

\begin{tabular}{|c|c|c|c|c|c|}
\hline \multirow[t]{3}{*}{ Parameter } & \multicolumn{2}{|c|}{$\begin{array}{l}\text { River Godavari water intake to } \\
\text { the plant }\end{array}$} & \multirow[t]{3}{*}{$\begin{array}{l}\text { TSPCBLi } \\
\text { mits }\end{array}$} & \multirow{2}{*}{\multicolumn{2}{|c|}{$\begin{array}{l}\text { Treated waste water discharged } \\
\text { from the Plant } \\
\text { March } 2006\end{array}$}} \\
\hline & \multicolumn{2}{|c|}{ March 2006} & & & \\
\hline & 17.03 .2006 & 31.032006 & & 17.03 .2006 & 31.03 .2006 \\
\hline $\mathrm{pH}$ at $25^{0} \mathrm{C}$ & 8.6 & 8.2 & $5.5-9.0$ & 7.3 & 7.5 \\
\hline SS(ppm) & - & - & 100 & 04 & 07 \\
\hline BOD3 (ppm ) & 1.5 & $<2$ & 30 & 1.5 & $<2.0$ \\
\hline COD (ppm ) & 5 & 11 & 250 & 16 & 18 \\
\hline TDS (ppm ) & 265 & 266 & 2100 & 16 & 15 \\
\hline $\begin{array}{l}\text { Oil and Grease } \\
(\mathrm{ppm})\end{array}$ & - & & 10 & $<1$ & $<1$ \\
\hline Sulphide (ppm) & - & $6 \mathrm{ClO}$ & 2.0 & $<0.050$ & $<0.050$ \\
\hline $\begin{array}{l}\text { Sulphate as } \mathrm{SO}^{4-} \\
-(\mathrm{ppm})\end{array}$ & 31 & 14 & 1000 & 094 & 09 \\
\hline $\begin{array}{l}\text { Chloride as } \mathrm{Cl}^{-} \\
(\mathrm{ppm})\end{array}$ & 18 & 20 & 1000 & & 08 \\
\hline
\end{tabular}

Table 2 : Water quality parameters of river Godavari and treated waste water quality discharged to river Godavcari from chemical process plant at Manuguru.

\begin{tabular}{|c|c|c|c|c|c|}
\hline \multirow[t]{3}{*}{ Parameter } & \multicolumn{2}{|c|}{$\begin{array}{l}\text { River Godavari water intake to } \\
\text { the plant }\end{array}$} & \multirow[t]{3}{*}{ TSPCBLimits } & \multirow{2}{*}{\multicolumn{2}{|c|}{$\begin{array}{l}\text { Treated waste water } \\
\text { discharged from the Plant } \\
\text { May } 2006\end{array}$}} \\
\hline & \multicolumn{2}{|l|}{ May 2006} & & & \\
\hline & 17.05 .2006 & 31.052006 & & 17.05 .2006 & 31.05 .2006 \\
\hline $\mathrm{pH}$ at $25^{\circ} \mathrm{C}$ & $8.4 \bigcirc$ & $8.5-00$ & $5.5-9.0$ & 7.9 & 7.9 \\
\hline SS(ppm) & - & -7 & 100 & 03 & 04 \\
\hline BOD3 (ppm ) & 1.8 & 1.5 & 30 & 1.5 & 1.2 \\
\hline COD (ppm ) & 24 & 16 & 250 & 13 & 15 \\
\hline TDS (ppm ) & 250 & 1.5 & 2100 & 18 & 15 \\
\hline $\begin{array}{l}\text { Oil and Grease } \\
(\mathrm{ppm})\end{array}$ & - & - & 10 & 01 & $<1.0$ \\
\hline Sulphide (ppm) & - & - & 2.0 & $<0.05$ & $<0.05$ \\
\hline $\begin{array}{l}\text { Sulphate as } \mathrm{SO}^{4-} \\
(\mathrm{ppm})\end{array}$ & 24 & 20 & 1000 & 07 & 07 \\
\hline $\begin{array}{l}\text { Chloride as } \mathrm{Cl}^{-} \\
\text {(ppm) }\end{array}$ & 28 & 24 & 1000 & 09 & 06 \\
\hline
\end{tabular}


Table 3 : Water quality parameters of river Godavari and treated waste water quality discharged to river Godavcari from chemical process plant at Manuguru.

\begin{tabular}{|c|c|c|c|c|c|}
\hline \multirow[t]{3}{*}{ Parameter } & \multirow{2}{*}{\multicolumn{2}{|c|}{$\begin{array}{c}\text { River Godavari water intake to } \\
\text { the plant } \\
\text { July } 2006 \\
\end{array}$}} & \multirow[t]{3}{*}{$\begin{array}{l}\text { TSPCBLi } \\
\text { mits }\end{array}$} & \multirow{2}{*}{\multicolumn{2}{|c|}{$\begin{array}{c}\text { Treated waste water discharged } \\
\text { from the Plant } \\
\text { July } 2006 \\
\end{array}$}} \\
\hline & & & & & \\
\hline & 18.07 .2006 & 26.07 .2006 & & 18.07 .2006 & 26.07 .2006 \\
\hline $\mathrm{pH}$ at $25^{\circ} \mathrm{C}$ & 7.9 & 8.0 & $5.5-9.0$ & 7.3 & 7.2 \\
\hline $\mathrm{SS}(\mathrm{ppm})$ & - & - & 100 & 2 & 2 \\
\hline BOD3 (ppm ) & $<2$ & 1.5 & 30 & 1.2 & 1.2 \\
\hline $\mathrm{COD}(\mathrm{ppm})$ & 15 & 13 & 250 & 14 & 16 \\
\hline TDS (ppm ) & 96 & 117 & 2100 & 16 & 20 \\
\hline $\begin{array}{l}\text { Oil and Grease } \\
(\mathrm{ppm})\end{array}$ & - & & 10 & $<1$ & $<1$ \\
\hline Sulphide (ppm) & - & 3 & 2.0 & $<0.05$ & $<0.05$ \\
\hline $\begin{array}{c}\text { Sulphate as } \mathrm{SO}^{4}- \\
(\mathrm{ppm})\end{array}$ & 16 & 11 & 1000 & 05 & 05 \\
\hline $\begin{array}{r}\text { Chloride as } \mathrm{Cl}^{-} \\
(\mathrm{ppm})\end{array}$ & & & 1000 & 02 & 03 \\
\hline
\end{tabular}

\section{Discussions:}

Water is absolutely essential not only for survival of human beings, but also for animals, plants and all other living beings. Water is scarce and valuable resource and it is highly essential for the survival of mankind(Nighojkar Abhineet and ER, D. Dohare,2014).

Nahar et.al (2016) studied effluents discharged to the main river and the water quality parameters such as temperature, $\mathrm{pH}$, Electrical Conductivity, Total Dissolved Solids, Dissolved Oxygen, Alkalinity, Hardness, Sodium, Potassium, Phosphate, Sulphate, Chloride, etc. and observed that most of the parameters exceeded the permissible limits. Manjusha et.al (2013) assessed Water Quality of the River
Godavari, at Ramkund for $\mathrm{pH}$, Chloride, Total Dissolved Solid (TDS), Dissolved Oxygen (DO), Biochemical Oxygen Demand (BOD) etc. Bilotta and Brazier(2008) found SS are an extremely important cause of water quality deterioration leading to aesthetic issues, higher costs of water treatment, a decline in the fisheries resource, and serious ecological degradation of aquatic environments.

The pollution of water is increased due to human population, industrialization, the use of fertilizers in agriculture and man-made activity. Parameters such as temperature, turbidity, nutrients, hardness, alkalinity, dissolved oxygen, etc. are some of the important factors that determines the growth of living organisms in the water body (Smitha 2013).

Table 4: Water quality parameters of river Godavari and treated waste water quality discharged to river Godavcari from chemical process plant at Manuguru.

\begin{tabular}{|c|c|c|c|c|c|}
\hline \multirow[t]{3}{*}{ Parameter } & \multirow{2}{*}{\multicolumn{2}{|c|}{$\begin{array}{l}\text { River Godavari water intake to the } \\
\text { plant } \\
\text { Septeber } 2006\end{array}$}} & \multirow{3}{*}{$\begin{array}{l}\text { TSPCB } \\
\text { Limits }\end{array}$} & \multirow{2}{*}{\multicolumn{2}{|c|}{$\begin{array}{l}\text { Treated waste water } \\
\text { discharged from the Plant } \\
\text { Septeber2006 }\end{array}$}} \\
\hline & & & & & \\
\hline & 19.09.2006 & 28.09.2006 & & 19.09 .2006 & 28.09 .2006 \\
\hline $\mathrm{pH}$ at $25^{\circ} \mathrm{C}$ & 7.3 & 7.9 & $5.5-9.0$ & 6.9 & 7.0 \\
\hline $\mathrm{SS}(\mathrm{ppm})$ & - & - & 100 & 2 & 2 \\
\hline BOD3 (ppm ) & 1.5 & $<2$ & 30 & 1.2 & 1.2 \\
\hline COD (ppm ) & 18 & 16 & 250 & 18 & 20 \\
\hline TDS (ppm ) & 122 & 150 & 2100 & 16 & 18 \\
\hline
\end{tabular}


International Journal of Trend in Scientific Research and Development (IJTSRD) ISSN: 2456-6470

\begin{tabular}{|c|c|c|c|c|c|}
\hline $\begin{array}{l}\text { Oil and Grease } \\
(\mathrm{ppm})\end{array}$ & - & - & 10 & 1.6 & 1.8 \\
\hline Sulphide (ppm) & - & - & 2.0 & $<0.05$ & $<0.05$ \\
\hline $\begin{array}{l}\text { Sulphate as } \mathrm{SO}^{4-} \\
(\mathrm{ppm})\end{array}$ & 15 & 12 & 1000 & 3 & 4 \\
\hline $\begin{array}{l}\text { Chloride as } \mathrm{Cl}^{-} \\
\text {(ppm) }\end{array}$ & 9 & 9 & 1000 & 5 & 2 \\
\hline
\end{tabular}

Table 5: Water quality parameters of river Godavari and treated waste water quality discharged to river Godavcari from chemical process plant at Manuguru.

\begin{tabular}{|c|c|c|c|c|c|}
\hline \multirow[t]{3}{*}{ Parameter } & \multicolumn{2}{|c|}{$\begin{array}{l}\text { River Godavari water intake to } \\
\text { the plant }\end{array}$} & \multirow[t]{3}{*}{$\begin{array}{l}\text { TSPCBLi } \\
\text { mits }\end{array}$} & \multicolumn{2}{|c|}{$\begin{array}{l}\text { Treated waste water discharged } \\
\text { from the Plant }\end{array}$} \\
\hline & \multicolumn{2}{|c|}{ November2006 } & & \multicolumn{2}{|c|}{ November2006 } \\
\hline & 22.11.2006 & 30.112006 & & 22.11 .2006 & 30.112006 \\
\hline $\mathrm{pH}$ at $25^{0} \mathrm{C}$ & 7.5 & 7.6 & $5.5-9.0$ & 7.4 & 7.4 \\
\hline $\mathrm{SS}(\mathrm{ppm})$ & - & $-\quad \mathrm{CO}$ & 100 & 3 & 2 \\
\hline BOD3 (ppm ) & 1.6 & 2.0 & $30+0$ & 1.3 & 1.4 \\
\hline COD (ppm ) & 12 & $13 \bigcirc 9$ & 250 & 16 & 18 \\
\hline TDS (ppm ) & 227 & 207 & 2100 & 16 & 20 \\
\hline $\begin{array}{l}\text { Oil and Grease } \\
(\mathrm{ppm})\end{array}$ & & - & 10 & $019 \mathrm{a}$ & 01 \\
\hline Sulphide (ppm) & $60^{\prime}$ & - & 2.0 & $<0.05$ & $<0.055$ \\
\hline $\begin{array}{l}\text { Sulphate as } \mathrm{SO}^{4-} \\
-(\mathrm{ppm})\end{array}$ & $9)$ & $8=11$ & 1000 & 04 & 05 \\
\hline $\begin{array}{l}\text { Chloride as } \mathrm{Cl}^{-} \\
(\mathrm{ppm})\end{array}$ & 140 & 13 & $\begin{array}{l}1000 \\
\text { and }\end{array}$ & 20 & 2 \\
\hline
\end{tabular}

Deshmukh (2015) recorded the maximum concentration of TDS during summer and increase in chloride concentration due to increase in sewage contamination.

Table 6: Water quality parameters of river Godavari and treated waste water quality discharged to river Godavcari from chemical process plant at Manuguru

\begin{tabular}{|c|c|c|c|c|c|}
\hline \multirow[t]{3}{*}{ Parameter } & \multicolumn{2}{|c|}{$\begin{array}{l}\text { River Godavari water intake to } \\
\text { the plant }\end{array}$} & \multirow[t]{3}{*}{$\begin{array}{l}\text { TSPCBLi } \\
\text { mits }\end{array}$} & \multirow{2}{*}{\multicolumn{2}{|c|}{$\begin{array}{l}\text { Treated waste water discharged } \\
\text { from the Plant } \\
\text { January } 2007\end{array}$}} \\
\hline & \multicolumn{2}{|c|}{ January 2007} & & & \\
\hline & 22.01 .2007 & 31.012007 & & 22.01 .2007 & 31.012007 \\
\hline $\mathrm{pH}$ at $25^{\circ} \mathrm{C}$ & 7.8 & 7.5 & $5.5-9.0$ & 7.5 & 7.8 \\
\hline $\mathrm{SS}(\mathrm{ppm})$ & - & - & 100 & 2 & 2 \\
\hline BOD3 (ppm ) & 1.2 & 1.2 & 30 & 1.6 & 1.6 \\
\hline COD (ppm ) & 15 & 13 & 250 & 16 & 16 \\
\hline TDS (ppm ) & 246 & 250 & 2100 & 33 & 30 \\
\hline $\begin{array}{l}\text { Oil and Grease } \\
(\mathrm{ppm})\end{array}$ & - & - & 10 & 01 & 01 \\
\hline Sulphide (ppm) & - & - & 2.0 & $<0.05$ & $<0.05$ \\
\hline $\begin{array}{l}\text { Sulphate as } \mathrm{SO}^{4-} \\
(\mathrm{ppm})\end{array}$ & 10 & 08 & 1000 & 4 & 5 \\
\hline $\begin{array}{c}\text { Chloride as } \mathrm{Cl}^{-} \\
(\mathrm{ppm})\end{array}$ & 21 & 20 & 1000 & 3 & 3 \\
\hline
\end{tabular}


Abd El-Gawad, (2014) discussed the desired development for effective removal of oil and grease as emerging pollutants and reported the applications, efficiencies, and challenges of oil and grease wastewater treatment from industrial wastewater and municipal water stream. Patil and others (2008) carried out Physicochemical analysis of Pochampad Dam back water of Godavari river on Maharashtra and Andhra Pradesh border. Patil and Gorade (2013) Assessed the physicochemical properties of Godavari River Water at Trimbakeshwar \& Kopargaon, Maharashtra. Phosphate levels in the water are the prime consideration to assess the quality of water for its best utilization like drinking, irrigation, fisheries etc. Eswari et.al(2015).

National River Water quality (NRWQ) standard is $500 \mathrm{mgl}$ for drinking and $2100 \mathrm{mgl}$ for irrigation water Singh et.al (2008). The water quality assessment involves the analysis of physicochemical, biological and microbiological parameters that reflect the biotic and abiotic status of ecosystem Verma et.al (2012).

\section{CONCLUSION:}

The phisico chemical characteristics of water samples studied were observed well within permissible limits prescribed by TSPCB. The altered physico chemical properties of water may bring it to be unfit when water is reused. The feasibility of any water recycling technique at an economical level depends on cost of construction, maintenance and operation. The treated waste water is reused in Heavy Water Plant for power generation and for other applications like irrigation and horticulture.

\section{ACKNOWLEDGEMENT:}

The first author, SS is thankful to the management of Heavy Water Plant, Manuguru for giving permission and providing all facilities for execution of research work. MASC is thankful to the Head, Dept. of Microbiology, Kakatiya University, Warangal for providing facilities.

\section{REFERENCES:}

1. Abd El-Gawad, H. S., (2014).Oil and Grease Removal from Industrial Wastewater Using New Utility Approach. Advances in Environmental Chemistry Volume 2014 (2014), Article ID 916878.
2. Bilotta, G.S. and Brazier, R.E.(2008). Understanding the influence of suspended solids on water quality and aquatic biota, Water Research 42, 2849-2861

3. Deshmukh, B. S.,(2015) Physico - Chemical Characteristic of Pravara River. International Journal of Research Studies in Biosciences (IJRSB) , 3, 14-18

4. Eswari, A., Amala, B., and Poonguzhali, T.V. Dr. (2015). Studies on the Physico Chemical Analysis of two different Water Bodies. International Journal of Science, Environment ISSN 2278-3687 (O) and Technology, Vol. 4, No 5, , 1377 - 1383

5. Goher M, (2002) Chemical studies on the precipitation and dissolution of some chemical element in lake Qarun, Ph.D. Thesis faculty of sciences, Al-Azhar University, Egypt.

6. Karthikeyan, T.P., Sashikumar, M. and Ramesh M. (2002): Physico-Chemical, biological and bacteriological studies of Kaduthur canal water of Amravati River, Tamilnadu. Poll. Res. 21(1): Pp. 21-23

7. Kashyap, V. R (2016). Physico-chemical analysis of various water samples of Rewa district (M.P.) India. International Journal of Applied Research; 2, 311-313

8. Nighojkar Abhineet and ER, D. Dohare (2014).Physicochemical parameter for Testing of present water quality of Khan River at Indore, International Research Journal of Environmental Science, 3 (4), 74-81.

9. Nahar, N., Lanon, M. A. H., Saha, B. \& Shaibur, M. R. (2016). Assessment of physico-chemical properties of water of Gorai river at Kushtia town in 2014: a case study. Journal of Science, Technology and Environment Informatics, 02, 5160 .

10. Manjusha Bhor, Prakash Kadave, Abhijit Bhor, Sheetal Bhor, Manisha Bhosale, Bholay A.D.(2013), Water Quality Assessment of the River Godavari, At Ramkund, Nashik, (Maharashtra), India. International Journal Of Engineering And Science. 2 ,64-68.

11. Mathivanan., V., P. Vijayan, Selvi Sabhanayakam and O. Jeyachitra (2007). An assessment of plankton population of Cauvery river with 
reference to pollution. Journal of Environmental Biology, 28, 523-526.

12. Meghla, N. T., Islam, M. S., Ali, M. A. \& Sultana, N. (2013). Assessment of physicochemical properties of water from the Turag River in Dhaka city, Bangladesh. International Journal of Current Microbiology Applied Science, 2, 110-122.

13. Narayana J, Puttaiah ET and Basavaraja D (2008) Water quality characteristics of Anjanapura reservoir near Shikaripur, District Shimoga, Karnataka. Journal of Aquatic Biology 23,59-63

14. Patil, A. M., Gaikwad, D. D., Pawar, R. P., Tayade,C Sdmvanshi, J. L, Akushkar, S. K.(2008).Physico- chemical analysis of Pochampad Dam back water of Godavari river on Maharashtra and Andhra Pradesh border. Pollut Res 27, 153-6.

15. Patil and Gorade (2013): Assessment of Physicochemical Characteristics of Godavari River Water at Trimbakeshwar \& Kopargaon, Maharashtra (India). Indian Journal of applied research, 3, 149-152.

16. Reddy VK, Prasad KL, Swamy M , Reddy R (2009) Physico-chemical parameters of Pakhal lake of Warangal District Andhra Pradesh, India. Journal of Aquatic Biology 24:77-80.

17. Singh, J., D.K. Agrawal and S. Panwar, 2008. Seasonal variation in different physicochemical characteristicsof Yamuna River water quality in proposed lakhwarproject influence area. Intl. J. Appl. Environ. Sci.,3, 107-117

18. Smitha (2013) Physico-chemical analysis of the freshwater at River Kapila, Nanjangudu Industrial Area, Mysore, India. International Research Journal of Environment Sciences 2,59-65.

19. Rahman, A. K. M. L., Islam, M., Hossain, M. Z. \& Ahsan, M. A. (2012). Study of the seasonal variations in Turag river water quality parameters. African Journal of Pure and Applied Chemistry, 6, 144-148.

20. Rani N, Sinha RK, Prasad K, Kedia DK (2011) Assessment of temporal variation in water quality of some important rivers in middle Gangetic Plains, India. Environ Monit Assess 174(14):401-415
21. Rump, H.H., and H. Krist (1992), Laboratory Manual for the examination of water, Waste water $\&$ soil, Second edition.

22. Verma P.U, Purohit A.R, Patel NJ (2012) Pollution status of Chandlodia Lake located in Ahmedabad Gujarat. International Journal of Engineering Research and Applications $2,1600-1610$.

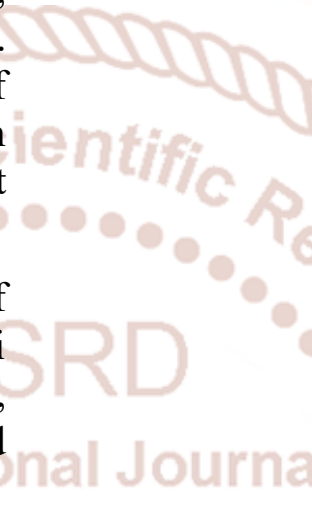

